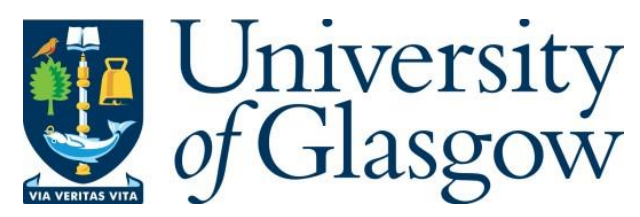

Clarke, J. (2018) The récit de filiation ouvrière and the unfinished business of fordism in twenty-first-century France. Modern and Contemporary France, 26(3), pp. 261-273. (doi:10.1080/09639489.2018.1447916)

There may be differences between this version and the published version. You are advised to consult the publisher's version if you wish to cite from it.

\title{
http://eprints.gla.ac.uk/158250/
}

Deposited on: 2 March 2018

Enlighten - Research publications by members of the University of Glasgow http://eprints.gla.ac.uk 
Title: The récit de filiation ouvrière and the unfinished business of Fordism in twenty-firstcentury France

\author{
Author information \\ Jackie Clarke \\ School of Modern Languages and Cultures \\ Hetherington Building \\ University of Glasgow \\ Glasgow G128RS \\ Jackie.Clarke@glasgow.ac.uk \\ @jackeeclarke \\ https://orcid.org/0000-0001-6080-2740
}




\section{The récit de filiation ouvrière and the unfinished business of Fordism in twentieth-century France}

As the articles in this special issue testify, the crisis of work that has been apparent in France since the turn of the twenty-first century has manifested itself in a number of social, psychological and cultural forms. ${ }^{1}$ From the development of the roman d'entreprise as a new literary genre to the emergence of la souffrance au travail as an object of medico-social discourse, the world of work has occupied an increasingly central place in French culture in recent years. This article considers the place of industry - and more specifically, the closed or closing factory-within this socio-cultural landscape. The ongoing significance of such sites within the French social imaginary was amply demonstrated when the visits of Emmanuel Macron and Marine Le Pen to the threatened Whirlpool plant in Amiens became one of the media flashpoints of the 2017 presidential election campaign (see http://www.lemonde.fr/election-presidentielle-2017/article/2017/04/27/presidentielle-quand-

whirlpool-precipite-1-affrontement-macron-le-pen_5118529_4854003.html). As Audrey Evrard's contribution to this collection illustrates $(2018,5)$, the closed factory has also become a recurring object of concern and fascination in French cultural production. The implications of this preoccupation with the disappearing industrial workplace are explored here in relation to a cluster of texts that appeared in the early 2000s and have been described (Grenouillet 2012; Viart 2009) as 'récits de filiation ouvrière'.

The term récit de filiation was coined by Dominique Viart to describe an emerging genre that engaged with personal histories, not in the form of autobiography or autofiction, but through an exploration of the life of the author's parent(s) (Viart 2009, 96). A number of these works are 
written by the sons and daughters of working-class parents and explore issues of class identity (see Grenouillet 2012,95), but my focus here is, more specifically, on three texts which have at their heart the phenomenon of factory or pit closures: Franck Magloire's Ouvrière (2002), Aurélie Filipetti's Les Derniers jours de la classe ouvrière (2003) and Martine Sonnet's Atelier 62 (2008). Each of these works evokes the demise of a particular industrial site or group of sites to which the author is linked via the working life of his or her father or mother. Filipetti, who is best known for her role as Minister of Culture in the Ayrault and Valls governments of 20122014, grew up in one of the iron and steel villages of northern Lorraine, near the border with Luxembourg, where her father, Angelo, and her grandfather (like many Italian immigrants in this locality) were miners. Sonnet and Magloire, on the other hand, are the children of workers who originated from rural Normandy and who, like thousands of other men and women in France in the decades after the Second World War, left the countryside for factory jobs: Amand Sonnet worked in the forge at Renault-Billancourt, while Nicole Magloire assembled domestic appliances at Moulinex in Cormelles-le-Royal on the outskirts of Caen.

Viart $(2009,97)$ has noted that the récit de filiation is typically characterized by a sense of historical and familial discontinuity or failed transmission from one generation to the next. In the case of Filipetti, Magloire and Sonnet this generation gap is doubled by a sense of class displacement, these children of workers having benefited from higher education and entered middle-class professions. But their texts also speak to a broader social and economic discontinuity that is linked to a process of deindustrialisation and economic restructuring. Indeed, while Amand Sonnet and Angelo Filipetti had died in 1986 and 1992 respectively, it is the 'loss' of the mine and the factory, more than the loss of the parent per se, that frames the works written in their honour: Atelier 62 was conceived as a response to the imminent demolition of the iconic 
Renault factory on the Ile Seguin (Sonnet 2012, 207), while the epigraph at the end of Les Derniers jours de la classe ouvrière notes that the Montrouge mine in Filipetti's village of Audun-le-Tiche was the last working iron mine in Lorraine when it closed in 1997. Similarly, Magloire's Ouvrière is set against the backdrop of the financial collapse and closure of Moulinex in 2001. Thus, these explorations of amily histories are also reflections on a collective historical experience.

Jean-Paul Engélibert $(2012,147)$ and Corinne Grenouillet $(2012,110)$ see such texts as 'tombeaux de la classe ouvrière' - that is, as memorials for a social group that has had its day. The metaphor of the tombstone implies a particular kind of temporal and affective relationship to the working-class world of the parents' generation: it speaks of a chapter closed, of finality and of mourning. These narratives and their critical reception as 'tombstones' can be seen as part of a wider set of interrogations about the 'end of the working class' which has emerged in France since the 1980s, as a period of economic restructuring and deindustrialisation has been accompanied by a process of post-Cold War ideological realignment. Up to this point, the twentieth century, and particularly the period since the Second World War, had been marked by what Xavier Vigna $(2012,11)$ has called 'la centralité ouvrière': that is, a sense that workingclass people were a socially and politically significant group who could influence the direction of the country. As the twentieth century drew to a close, in contrast, the number of industrial jobs and the power of organised labour dwindled (see Vigna 2012, 299-300, 288-295) and the working classes came to be seen as a group in decline: 'Hier encore essentiels pour déterminer l'avenir politique du pays', writes Vigna (2012, 282), 'les ouvriers deviennent au mieux invisibles, au pire vestiges d'un archaïsme à la fois social et politique.' Thus, while claims about 
the end of the working class are rooted in very real social and economic changes, their potential ideological implications also need to be interrogated.

The implications of the narrative of 'class death' are explored in the next section in relation to Filipetti's Les Derniers jours de la classe ouvrière-the text which (of the three discussed here) is most explicitly framed as a tombstone for the working class. However, I will go on to argue that Magloire and Sonnet's texts have a rather different temporal and affective relationship to the past that they evoke. With their focus on rural workers who entered the factory during France's postwar industrial expansion, these works function less as memorials to a much mythologised working-class identity, than as meditations on the half-fulfilled and halfbroken promises of Les Trente Glorieuses (Fourastié 1979). They have a kind of unfinished business with that past that is not adequately captured by the language of memorialisation. Indeed, as a cultural response to a process of social and economic reordering - and as symptoms of the crisis of work in contemporary France-these texts give voice not just to a sense of mourning but a sentiment of injustice. I will argue that they speak to what I have called the 'unfinished business of Fordism', a term which I will explain more fully below.

\section{Les Derniers jours de la classe ouvrière and the heritagization of class}

One feature of narratives of class death is that they tend to be sustained by a conflation of particular working-class cultures with a monolithic classe ouvrière, a conflation that has the depoliticising effect of relegating 'the working class' to the past. It is notable in this respect that the title 'Les Derniers jours de la classes ouvrière' functions quite differently from Magloire's 'Ouvrière'. The latter gestures towards a shared class experience but also to the intersection of class and gender, retaining a sense that this is the story of one woman; in contrast the 
identification of Filipetti's family history with that of 'la classe ouvrière' as a whole reflects the extent to which that history is bound up with one of the most mythologised sites of working-class culture - the mining community. ${ }^{2}$ In her portrait of this milieu, miners embody a heroic working-class masculinity, united in the face of danger: 'Ils descendent chaque matin, partent voler le feu sacré, avec au ventre la solidarité des copains et la peur de la mort. Entre eux, pas de collègues, rien que des camarades' (29). Steelworkers are figured (28) in similar ways:

Pour eux la lumière c'était l'acier ou la fonte en fusion, la couleur or dans les ténèbres de l'usine, son jour violent sur les visages trempés. Au moment où ils ouvraient le ventre du haut fourneau, le métal s'échappait puis, guidé par les hommes à travers les rigoles, les rails prenaient forme, et c'était la promesse de conquêtes futures, de monuments fabuleux destinés à chanter de par le monde l'héroïsme des hommes du fer.

A normative masculinity, associated with risk and conquest, with mastery of the elements (fire), serves here to valorise the worker, as the gender norm in effect operates to counter hierarchies of class and nationality that otherwise subordinate this group. In this way, Filipetti honours her father and others like him. Yet the conflation of the male hero worker of heavy industry with the figure of the working class as a whole occludes other working-class experiences, including twenty-first century ones.

It may seem paradoxical to see Les Derniers jours de la classe ouvrière as a depoliticising narrative, and not just because it was written by a politician. If professions such as mining have occupied a prominent position within representations of the working classes, it is partly because of their centrality within the labour movement and within class politics. This too is reflected in Filipetti's novel, as her family story is that of the rise and fall of French Communism: her father was a loyal party member and trade unionist who served as mayor of Audun-le-Tiche; her grandfather had died in Bergen-Belsen after being deported for resistance 
activity in 1944. The weight of this family legacy of resistance martyrdom is evoked in Les Derniers Jours, as is the complicity of the mine management who allowed the Gestapo to capture the men below ground, where they could not escape (19-25). Working-class resistance is contrasted with the collaboration of the patronat (20), in this case the de Wendel family who owned much of the Lorraine steel industry and ensured that production continued during the war, in the service of the Reich. The panorama offered of the battles of the labour movement in twentieth-century France also takes in the mobilization of 1968, remembered as a moment of joyful insubordination ('Etre un ouvrier n'était donc pas une honte', 99) and, in a chapter titled 'Le Grand Soir' (133), the election of Mittterrand in 1981. At the same time, the narration of these moments is interspersed with interrogations about the PCF's complicity with Stalinist repression: as the words of the Internationale ring out in one scene of a demonstration in 1968, Filipetti writes (101), 'il fallait chanter, chanter, pour oublier Prague, les chars russes, et les larmes de Dubček.'

Thus, the class death that Filipetti announces in Les Derniers jours is not just the decomposition of a social world built around the iron and steel industry, but the death of a certain political ideal of the working class. This is apparent in the way the narrative aligns the illness and death of the author's father with the collapse of communism in Eastern Europe:

Allongé sur son lit d'hôpital, il regardait le plafond, les yeux perdus, ailleurs, à des kilomètres plus à l'est... Comment pendant toutes ces années ne pas avoir compris...A la radio, on entendait les nouvelles du coup d'Etat. Les généraux de l'armée Rouge tentaient une reprise en main par la force. On voyait de nouveau des chars, comme en 56 à Budapest, comme en 68 à Prague, et partout ailleurs (78).

The coup d'Etat against Gorbatchev figures here as the death throes of a system that was always about repression. There is a sense of inevitability. To have been a party member is to have 
misunderstood, to have been on the wrong side of history; a later chapter returning to this theme is titled 'le mensonge déconcertant' (128). Thus, it is through a narrative of the death of a particular form of class politics, that Filipetti positions 'la classe ouvrière' (as both a social group and a political ideal) as a thing of the past.

The treatment of class in Les Derniers jours de la classe ouvrière can be understood as a form of heritagization. The anthropologist Jean-Louis Tornatore has observed that the emergence of a recognised industrial heritage in Lorraine has been closely linked with that of a regional identity that incorporates a positive story about the integration of (European) migrants: he calls this process 'l'invention de la Lorraine industrielle' $(2005 ; 2010)$ and charts its development from the struggles that took place in the wake of the closure of the Longwy steelworks in 1979, to the conversion of a blast furnace at Uckange into an industrial heritage park which opened to the public in 2007 (Tornatore 2005; 2006). The battle to save the steel industry was cast as a regional one in slogans such as 'La Lorraine vivra' or 'Lorraine cœur d'acier' (the name of a radio station created in Longwy in 1979.) Tornatore contends, however, that while initial attempts by activists to develop industrial memory projects in the wake of site closures were an extension of this social conflict, a more consensual discourse has since developed which positions the industrial past less as a site of class struggle, than as a site of cultural identity: the figure of the 'ouvrier' becomes 'l'homme de fer', 'l'étranger intégré' (2010, 35-6). ${ }^{3}$ As Tornatore observes in a footnote (2010, 35), Filipetti's text also exemplifies this tendency. In a passage on the place of working-class people in History, she writes, for example:

L'Histoire ne retiendrait plus le nom des seuls maréchaux aux mains rouges, le nom des seuls propriétaires aux généalogies crasses. L'Histoire, ce serait toutes leurs vies à eux aussi, et celles de leurs pères, venus d'Italie, de Pologne, et d'ailleurs, jetés en une seule 
et même offrande aux monstres de la terre, aux gardiens des Enfers. Eux aussi avaient donné leur sang pour leur pays, la France, pour un combat, l'acier. Et encore, les guerres durant, avaient-ils fait leur devoir aussi bien que tant d'autres, souvent en première ligne, sur ces frontières fragiles (17-18).

The narrator refers here to the aspirations of the people of Villerupt ('fils et filles d'ouvriers') who, against the backdrop of steel industry closures ('La Lorraine Vivra', 18), performed a show about their community's history. However, the passage could equally be read as a statement about Filipetti's own literary project. What starts here as a claim about class (about the privileges of the officer and property-owning classes versus, implicitly, 'les classes populaires') is subsumed into a narrative of migrant integration and masculine service to the nation. Understood in this way, it is suggested, 'l'ouvrier' can take his place in History. This figure of the worker is, to use Tornatore's term, 'patrimonialisable' as part of a narrative of Lorraine as a melting pot (36). One might go further and argue that in Filipetti's text, 'l'homme de fer' is not just 'patrimonialisable' but 'patrimonialisé': he is part of a past that is finished and is recalled or handed on to the next generation only as a cultural identity.

\section{'Ce que l'on détruit à Billancourt...'}

The threat of disappearance or death also inhabits Sonnet's Atelier 62 and Magloire's Ouvrière, but, as we will see, the demise of the factory takes on a rather different meaning here. Indeed, in an essay on Atelier 62, Laurent Demanze $(2016,83)$ hints at the ways in which such texts resist the commemorative mode, even as they mark what appears to be the end of an era: 
Ecrire l'usine, cela signifie ainsi pour bien des écrivains saisir un état disparu du travail, dans un geste mélancolique de restitution qui résiste à l'historicisation d'une mémoire. Telle restitution oscille entre tombeau et anti-tombeau, pour préserver une mémoire mais se tenir à distance des commémorations qui figent l'ondoyance et l'aura des souvenirs.

This oscillation between 'tombeau' and 'anti-tombeau' locates the text in a kind of temporal entre-deux: there is an acknowledgement that something has ended and, at the same, a refusal to see all that the factory represents pass into history. For Sonnet, this refusal begins with an affective response, as she makes clear in her account of the moment when she decided to write about Billancourt:

Devant des photographies d'Antoine Stéphani (Stéphani \& Bon, 2004) faites dans [1]es murs [de Billancourt] juste avant le début de la démolition, je prends brutalement conscience que la disparition de cette usine du paysage parisien m'est absolument insupportable en ce qu'elle signifie la négation de toutes les vies qui lui ont été suspendues pendant un siècle - et parmi elles, celle de mon père, donc la mienne. Je suis dès lors saisie par la nécessité impérieuse de résister à la démolition en réedifiant par l'écriture, seul outil à ma disposition, ce que l'on détruit à Billancourt. $(2012,207)$

The impulsion to write is rooted in a profound emotional response to the imminent disappearance of the factory, but the sentiment expressed is one of revolt rather than mourning. Sonnet situates her work very explicitly in relation to a politics of visibility, moved as she is, not just to honour a world that has gone, but to resist a threat of erasure in the present. Similarly, in Ouvrière, Magloire alludes in the narrative voice of his mother (21), to his own motivation for writing: 'cette histoire de laisser des traces dont il me rabat les oreilles...' (my emphasis). There is certainly a sense of finality that runs through these texts, expressed, for example, in the language 
of death and grief (Magloire 2004, 151, 159; Sonnet 2008, 47) or in the opening lines of Atelier 62 (9) which find 'le père' scouring shoe shops for a particular type of shoe he had worn his whole life, 'et un jour plus personne dans les magasins de chaussures, sauf lui, pour savoir ce que c'était. «Un modèle qui ne se fait plus »'. The latter phrase appears as much a statement about the author's father (and all that he represents) as about his footwear. Nonetheless there is a tone of defiance in these attempts to reconstitute the disappearing social world of Moulinex and Billancourt, something which is largely absent in Filipetti's work.

To describe these texts as 'tombeaux de la classe ouvrière' is also to risk overlooking the extent to which 'la classe ouvrière' is an ambivalent site in Atelier 62 and Ouvrière. Indeed, if we can read these works as histories of the French working class, they are histories that register the fragmented nature of that social group and the hierarchies within it (See Vigna 2012, 201-2). Both works testify to the experiences of those who left the countryside for the factory during the three decades of economic growth that followed World War Two. Amand Sonnet gave up his blacksmith's workshop near Céaucé in the Orne for the vast Renault plant at Billancourt in 1951. Unlike Angelo Filipetti, but like many new rural entrants to industry, he had had little or no contact with trade union culture. Although Martine Sonnet turns in places to the trade union press and to records of workers' delegates meetings in an attempt to reconstruct what it meant to work at Billancourt (e.g. 57-59, 65-67), this effort of historical reconstitution remains quite separate from her recollections of her father and her childhood: her text is structured in pairs of alternating chapters, those with Arabic numerals drawing on personal memories and family memorabilia, while those with Roman numerals are based on documentary research. This reinforces the sense of Amand Sonnet's isolation from a certain idea of Billancourt as the heart of French labour militancy. He also appears to have found little in the way of workplace 
sociability or camaraderie at Renault: uninterested in cars as he did not have a driving licence, 'le Normand se coupe un peu des autres', 161). He was, in his daughter's words a 'forgeron propriétaire-récoltant' who lived for the occasions when he could return to his little plot of land in Normandy, tend his fruit trees and make cider or calvados (94-5).

Similarly, in Ouvrière, Nicole Magloire, who left the countryside to work in the provincial capital of Caen, is suspicious of unions, finding the language of organised labour foreign. She complains of the trade unionists' inability to 'trouver un ton juste et une syntaxe appropriée qui puissent traduire véritablement ce que nous vivons et ce que nous sommes' (62). Moulinex was a company with a stark sexual division of labour, with women largely confined to tasks such as assembly work that were categorised as semi-skilled (or to secretarial work), while men undertook skilled or supervisory roles. The French labour movement too was heavily male dominated. Nicole's character recalls that when women workers revolted at Moulinex in the 1970s, led not by a male shop steward but by one of their own-'apolitique et choisie tacitement par ses camarades d'atelier' (64) — the language was different:

Le chef d'équipe en prenait pour son grade, réputé en plus pour avoir la mauvaise habitude quand il rentrait de son travail de faucher des pommes de terre dans les champs...Voleur de patates !...Nous ne sommes pas des vaches à traire. . . ça parlait campagne (63).

Here rural culture provides a shared reference point, anchored in everyday life, which can be used to forge a language of insubordination. But such passages also illustrate the extent to which both gender and rural origins operate to position Nicole, and others like her, on the margins of a certain idea of the working class and, initially at least, the margins of the labour movement. Thus, both Sonnet and Magloire tell stories of workers who are in some sense outsiders within 
the working class (despite the growing numbers of women and workers from rural backgrounds in France's factories). In contrast to Angelo Filipetti, these are workers without class consciousness: as Nicole's character remarks, 'la conscience de classe...me paraît une chose bien obscure encore aujourd'hui' (26).

Sonnet, who is a historian by profession, is also careful to interrogate some of the more clichéd representations of the automobile factory, resisting the temptation to construct the postwar social and economic order as a golden age. She questions (35), for example, the triumphant newsreel images of factories that she remembers from her childhood, noting a preference for shots of the production line - a symbol of modernity in the 1950s — rather than the forges of workshop 62 which relied on older and therefore less photogenic technologies. One image of blacksmiths from her father's workshop was rejected for an album commissioned by Renault because it was 'trop à la Zola' according to its author, Willy Ronis (Sonnet 2008, 201). Indeed, while there is a strong sense of the dignity of the working man in Sonnet's text, and her descriptions of the physically depleting nature of the work align with a certain image of workingclass masculinity - the métallo de chez Renault as industrial hard man-there is also scepticism about discourse of the nobility of work: 'Noblesse: quelle noblesse? Des hommes qui incarnaient des restes de mythologies, on avait fait des bagnards' (35). The conditions and pace of work in the forge were such that smiths were generally unable to finish their careers there, being moved instead to lighter work as they got older, which also meant a loss of status and pay (Sonnet 2012, 212). To this extent, even the now enviable job security of those who worked for organisations like Renault in this period is relativized.

If class consciousness is absent and the myth of hero workers is exposed as a deception, what is, in Sonnet's words, 'ce que l'on détruit à Billancourt' $(2012,207)$ ? Ultimately, what the 
factory symbolises for Magloire and Sonnet is the hollowed out social promise of Fordism. As Jeremy Lane and John Marks have noted $(2011,418)$, Fordism can be understood not just as a technique of industrial organisation, but as 'an enduring pattern of production and consumption, whose effects manifested themselves at many levels of social and political life', notably in the period of postwar economic expansion known as Les Trente Glorieuses (Fourastié 1979). Both Moulinex and Renault are emblematic companies of that period, when cars and domestic appliances became available to the mass market. Their history is inseparable from what Lauren Berlant $(2011,1)$ calls the postwar 'fantasy of the good life': a good life defined in terms of job security, social mobility, access to consumer goods and the welfare state. Indeed, the link between the factory and the good life was perhaps particularly strong in France, where this period saw rapid urbanisation and industrialisation associated with a major transformation in living conditions. Between the mid-1950s, when Sonnet's family finally relocated to Paris, and the mid-1970s, when Magloire's mother was a young worker at Moulinex, the number of people employed in agriculture in their native region of Lower Normandy halved, while the number working in industry doubled (Noiriel 1986, 212). In Ouvrière, Nicole speaks of those who made the journey from the countryside to Caen as 'de jeunes salariés en quête d'une terre promise' (16). This new working-class population was drawn in, she reflects, by 'l'étrange connivence entre l'essor industriel et les débuts du rêve de l'habitat individuel clés en main (...) Faire construire... j'ai entendu l'écho de ces deux mots toute ma vie d'usine, à tel point que je ne peux plus les séparer' (16). This identification of the move from the countryside to the factory with the aspiration for a better standard of living finds an echo in Atelier 62. Amand Sonnet gave up his business as a blacksmith as the spread of tractors to the French countryside reduced demand for his services and a relative who worked for Renault convinced him 'que l'avenir c'était là' 
(18). For five years he travelled back and forwards to Normandy, until he was allocated a flat in a newly-built cité, allowing his wife and 5 children finally to join him in the Paris suburbs. Cramped and noisy, his daughter recalls, the new development was still better than the poor housing they had left behind - it gave the family, and others like them, access for the first time to the luxury of running water, radiators and inside toilets (30).

From this perspective, the factory becomes less a site of class death than a site of memory for the Fordist compromise - that is, a compromise between capital and labour, from which both were deemed to benefit materially in a system predicated on a virtuous circle of growth. ${ }^{4}$ On the shop floor, this meant that workers in companies such as Renault and Moulinex were expected to accept widespread recourse to repetitive semi-skilled work, high productivity, and strict labour discipline in return for higher wages and living standards. In a study of automobile factory workers from agricultural backgrounds, Alain Touraine and Orietta Ragazzi $(1975,19)$ found that the opportunity to improve one's standard of living was a strong driver for those who migrated from the countryside to Paris. A majority of those surveyed indicated that they would like to change jobs and Touraine and Ragazzi found (37-8) that economic factors-the prospect of a decent wage and better living conditions-were the primary motivation for staying in factory work. Although Touraine and Ragazzi saw this as an economistic outlook, these workers, many of whom were employed in low status semi-skilled jobs and did not identify with a trade, were also distinguished by the social aspirations they had for their children: 76 per cent said it was not desirable for the children of manual workers (ouvriers) to be workers like their parents (25-6).

While Nicole Magloire and Amand Sonnet differ in certain respects from the workers who participated in Touraine and Ragazzi's study (by gender, generation or type of post 
occupied), their stories, at least as told by their children, resonate with his findings. Both authors see their parent's working lives as a sacrifice, whereby arduous conditions are endured to make a better life for the family (the authors' own educational and professional success being a testament to this sacrifice). Sonnet notes that her father moved partly so that the children could complete their schooling close to where they lived (115), and that he wanted them to take more advantage of the social activities open to them in the their new location: 'Il est venu pour nous faire profiter de tout, il sue aux forges toute la semaine et nous le dimanche on ne bouge pas trop' (129). In Ouvrière there are long passages describing the factory ('la taule', 85) as a dehumanizing force, a monstrous system that subordinates individual bodies to its demands (92), but when Nicole asks herself (74-5), 'pourquoi suis-je là?’, she responds: ‘j'ai souhaité trouver un appartement, voulu l'équiper avec un canapé en simili cuir, d'une machine à laver, d'un téléviseur grand format.' Like the workers who participated in Touraine and Ragazzi’s study, Nicole's pursuit of the good life also means offering the chance of something better to the next generation: ‘je ne veux pas de cette hérédité ouvrière pour mes enfants’ (37). Thus, however oppressive the factory appears as a work environment, its dismantling operates as a signifier for the dismantling of this promise of a better future, a promise that underpinned and legitimized the Fordist social and economic order.

\section{Lost optimism: temporality and affect}

When the author of Atelier 62 remarks upon the photographic predilection in the 1950s and 1960s for shots of cars rolling off production lines (35) or of gigantic pieces of machinery (202), she is referring to an aesthetic in which the vastness of the workshop and the reproducibility of 
the mass-produced object gesture to the possibility of infinite growth. Such was the temporal horizon of productivist ideology in this period. A selection of Renault photographs, dating from 1956, now features on Sonnet's website (http://martinesonnet.fr/pages/Pochette_photos.html) and readers of Modern and Contemporary France may also recognize this type of imagery from Kristin Ross's 1995 study Fast Cars, Clean Bodies. ${ }^{5}$ Antoine Stéphani's 2004 photographs, which moved Sonnet to write about Billancourt, include shots that reproduce some of the formal features of the 1950s images: they show long galleried workshops disappearing into the distance and sequences of repeating objects, in this case, cloakroom lockers. But what used to signify optimism now appears abandoned and in a state of ruination. ${ }^{6}$ This is surely part of what Sonnet is responding to when she describes these images as 'photos qui prennent à la gorge' (http://remue.net/spip.php?article1477). Her texte-usine $e^{7}$ registers not just the disappearance of a place marked by the labour of her father and thousands like him, but the disintegration of a historically specific form of cultural optimism.

To see such texts in terms of memorialisation is to suggest that they honour a finished past. Indeed, one of the limitations of the language of memory and mourning is that, by applying to the social world metaphors based on the individual mind and body, it frames historical developments as a series of births and deaths, a sequence of completed epochs. Another way of thinking about temporality and affect is offered by the work Lauren Berlant. Berlant $(2011,1)$ coins the term 'cruel optimism' to designate the condition of living in the ruins of the post-1945 'fantasy of the good life' without being able to give up on it entirely. Her work draws on a corpus of material that expresses what she sees (19) as 'the new affective languages of the contemporary global economy in Europe and the United States - languages of anxiety, contingency, and precarity - that take up the space that sacrifice, upward mobility, and 
meritocracy used to occupy'. Films like Laurent Cantet's Ressources humaines (1999), she argues (3, 200-212), dramatize adjustment to this contemporary social and economic world in which what had once seemed foundational (the promise of the good life) is transformed into a relation of cruel optimism. The interest of Berlant's approach for my purposes here is that by framing post-Fordist affect in terms of adjustment rather than commemoration she directs our attention to what is unfinished.

Berlant's focus is on works that are more concerned with constructing everyday life in the ruins, than with the history that preceded ruination, but the corpus of cross-generational narratives discussed here could be read as another symptom of the process of adjustment that she identifies. Both Sonnet and Magloire deal with an imminent threat of erasure rather than a world that has long disappeared, and the sense of generational discontinuity in these texts is always troubled by a desire for reconnection to the parent's past and what it stands for. Thus, while Filipetti's past is a more settled one, the desire to bridge the historical gap, to salvage something from a process of ruination unfolding before their eyes is expressed in Magloire and Sonnet's texts in the form of a quest or investigation. Both stage their own research within the text, Magloire (the only one of the three authors who is writing about a living parent) by evoking interviews or writing sessions with his mother, and Sonnet by making visible the process of archive research. Thus, in a passage that speaks to the author's sense of class displacement as at once a barrier and a stimulus for his literary project, Nicole Magloire's textual alter ego reflects (30): '...je le vois bien quand nous travaillons à écrire ce livre, il échafaude, dresse des passerelles entre lui et moi, des mots qui lui appartiennent et qui me ressemblent, mais sans être les miens'. Likewise, Sonnet draws on her training as a historian when she reports (14-15), '[c]e que je sais maintenant des forges', citing information found 'dans les cartons d'archives de la 
Société histoire du Groupe Renault' and in a 1972 issue of the CGT paper Voix de l'Usine Renault. Archive research serves for Sonnet as means of trying to fill a gap left by her father's silence about his working life, and by his death. ${ }^{8}$ But these intimate family dramas of separation and reconnection are also understood as part of a historical process that is ongoing.

The contemporary world of work hovers over these narratives, such that their authors, as products of a previous order, now appear to embody a historical anomaly. While Sonnet, Magloire and Filipetti benefited in many ways form the social world they look back on, growing up with a better standard of living and more educational opportunities than the previous generation, this 'ascenseur social' (to adopt a widely-used metaphor) is clearly seen to have stopped. Transmission has failed as mass unemployment and precarity have become the norm. This is tackled most explicitly in Ouvrière which charts (102) the arrival of temps in the Moulinex factories in the second half of the 1980s and (104-5) the worries of older workers about their children's prospects: Nicole's son appears as the exception here, as her colleagues speak of children struggling to get qualifications, only to enter a cycle of short-term contracts. In this way the Trente Glorieuses are revealed as an exceptional moment rather than an irreversible achievement or acquis.

At the same time, the vantage point from which these texts are written is one where the possibility of the good life was always at best precarious and hard won, and at worst illusory. For Filipetti, the lost optimism in question is that of Communism. For Sonnet, the sense that her father's generation was somehow deceived is captured in the telescoping of rural and industrial decline in Atelier 62, as the narrative of leaving the land merges with that of the loss of the factory. Sonnet registers her perplexity on reading in Alain Touraine's 1955 thesis on the evolution of work at Renault that her father's profession was already disappearing. 'Est-ce que 
ça se sentait déjà à l'atelier 62 dès 1955, que la comédie était jouée?' Her father believed the factory was the future, 'mais sa profession avait déjà vécu, à Billancourt aussi bien qu'au fin fond du bocage' (84). The Trente Glorieuses all but disappear in this alternative chronology, in which the exode rural and the decline of the figure of the métallo merge into one. The fantasy of a good life through industry reads here as a cruel deception. Similarly, in Ouvrière, Nicole Magloire feels in retrospect that she was duped: ' $\mathrm{j}$ 'ai conquis l'ordinaire les années passant, et j'ai rêvé au futur et au confort d'objets supplémentaires que je pourrais acquérir pour parfaire ce quotidien...comme tous, ouvriers ou pas...nous autres, nous nous sommes laisse engloutir à notre façon, emporter par leur miroitement, simplement nous ne sommes pas tombés du bon côté de la vitrine' (75). Having been lulled into passivity by this consumerist dream, she suggests, she now finds her voice through her son's book: 'mon fils a raison, ce livre est l'occasion unique de comprendre... pour moi d'abord... et de faire entendre...il est ma révolte sourde et différée' (75). For both Magloire and Sonnet, there is a sense that their parents' generation has been betrayed and that this wrong must be righted.

I have argued here that there is more to these récits de filiation ouvrière than the memorialization of the working class. Not only is the latter a less stable object than the narrative of class death might suggest, but the temporal and affective frameworks within which the texts situate industrial workplaces and working-class lives do not necessarily conform to a logic of commemoration. Atelier 62 and Ouvrière point to another kind of process at work, where the disappearing factory comes to stand for a form of social optimism that is now in ruins, and the textual restitution of the factory worker's life operates as a form of defiance in the face of this loss. The apparent resonance of these narratives, both of which received coverage in major national media outlets such as France Culture, Le Monde des Livres or Libération, underlines the 
way in which they speak to the contemporary crisis of work in France. Indeed, it appears that many readers recognized their own family experience in Sonnet's work and contacted her to share their stories. The use of 'des archives brutes' $(2012,213)$ with minimal commentary from the author facilitated this sense of connection, she believes:

Atelier 62 fournirait donc des preuves d'existence sensibles—et d'autant plus sensibles que portées parallèlement aux archives par une voix d'enfant-de tout un pan de l'aventure ouvrière, quand certains voudraient faire croire que celle-ci est terminée. La crise économique actuelle, contredisant la certitude optimiste des travailleurs de force des Trente glorieuses que les choses seraient plus aisées pour leurs descendants, incite précisément ces descendants, qui se croyaient solidement intégrés aux classes moyennes urbaines, à s'inquiéter pour l'avenir de leurs propres enfants et à reconsidérer leurs trajectoires. La bonne réception du livre tient sans doute aussi à cette sensibilité aiguë aux conséquences de la panne de l'ascenseur social; il peut fournir un arrière-plan rétrospectif aux interrogations que celle-ci suscite $(2012,215)$.

In other words, both the aspirations of the past and the uncertainties of the present should be central to our understanding of the significance of texts such as Sonnet's. If the disappearing factory is such a potent symbol in France today, it is at least partly because of its capacity to express these very contemporary concerns.

\section{References}

Berlant, L. 2011. Cruel Optimism. Durham, NC: Duke University Press. 
Demanze, L. 2016. 'Le Texte-usine de Martine Sonnet.' In Ecrire le travail au XXI siècle. Quelles implications politiques?, edited by A. Adler et M. Heck, 83-92. Paris: Presses Sorbonne Nouvelle.

Engélibert, J-P. 2012. 'Tombeaux de la classe ouvrière: Filipetti, Magloire, Sonnet.' La Licorne 103: $147-159$

Evard, A. 2018. 'Rêve d'usine (Luc Decaster 2003): presenting the vanishing workplace' Modern and Contemporary France 26 (3), 1-15 https://doi.org/10.1080/09639489.2018.1424707

Filipetti, A. 2003. Les Derniers jours de la classe ouvrière. Paris: Stock.

Fourastié, J. 1979. Les Trente Glorieuses où la révolution invisible. Paris: Fayard.

Grenouillet, C. 2012. 'Le Monde du travail dans les récits de filiation ouvrière.' Intercâmbio 5: 94-113.

Harvey, D. 1990. The Postmodern Condition: An Enquiry into the Origins of Cultural Change. Oxford: Blackwell

Hatzfeld, N., Michel, A.P. and Rot, G. 2006. 'Filmer le travail au nom de l'entreprise ? Les films Renault sur les chaînes de production (1950-2005)'. Entreprises et histoire 44 (3): 25-42.

Lane, J.F. and Marks, J. eds. 2011. Special issue on Figurations of Work in Post-Fordist France. Modern and Contemporary France 19 (4).

Leveratto, M. and Montebello, F. 2001. 'Faire l'histoire des hommes du fer'. In Une histoire à soi. Figurations du passé et localités, edited by A. Bensa and D. Fabre. Paris : Maison des sciences de l'homme.

Magloire, F. 2004 [1 ${ }^{\text {st }}$ ed.2002]. Ouvrière Paris: Editions de l'Aube. 
Michel, A.P. 2017. 'Le travail à la chaîne en images. Les documents visuels face à l'histoire industrielle de Renault' Images $d u$ Travail, Travail des Images 3 http://imagesdutravail.edel.univ-poitiers.fr/index.php?id=1249

Noiriel, G. 1986. Les Ouvriers dans la société française. Paris: Seuil.

Sonnet, M. 2008. Atelier 62. Le temps qu'il fait.

Sonnet, M. 2012. 'Un récit littéraire du travail en friction avec les sciences sociales.' Intercâmbio 5: 204-219.

Stéphani, A. and Bon, F. 2004. Billancourt. Paris: Cercle d'Art.

Tornatore, J-L. 2005. 'L'Invention de la "Lorraine industrielle". Note sur un processus en cours.' Ethnologie française 35 (4): 679-689.

Tornatore, J-L. 'Trou de mémoire. Une perspective post-industrielle de la "Lorraine sidérurgique"'. In La Mémoire de l'industrie: de l'usine au patrimoine, edited by J-C Daumas, 49-80. Besançon: Presses universitaires de Franche-Comté.

Tornatore, J-L 2010. L'Invention de la Lorraine industrielle. Paris: Riveneuve éditions.

Touraine, A. and Ragazzi, O. 1975. Ouvriers d'origine agricole. Paris: Editions d'aujourd'hui.

Viart, D. 1999. 'Filiations littéraires.' In États du roman contemporain. Écritures

contemporaines 2, edited by J. Baetens and D. Viart, 115-139. Paris: Lettres modernes Minard. Viart, D. 2009. 'Le Silence des pères au principe du « récit de filiation »' Etudes françaises 45(3): 95-112.

Vigna, X. 2012. Histoire des ouvriers en France au XXe siècle. Paris: Perrin. 
${ }^{1}$ See also the 2011 special issue on 'Figurations of Work in Post-Fordist France' Modern and Contemporary France 19 (4), guest edited by Jeremy F. Lane and John Marks.

${ }^{2}$ On the mythology of the miner as 'haute figure du prolétariat' in postwar France, see Noiriel 1986, 208. ${ }^{3}$ Marc Leveratto and Fabrice Montebello (2001, 63-4) note a similar process at work in the evolution of the Festival du film italien held in the former mining town of Villerupt, which began in 1976 as an initiative of the local working-class Italian population and the Communiste mairie, but whose social or class dimensions have increasingly been subsumed into a broader project of promoting Italian culture.

${ }^{4}$ On Fordism and the idea of the Fordist compromise see David Harvey (1990), esp. 132-4

${ }^{5}$ Renault had its own photograph service and the company archives contain a collection of over 400000 images. See Hatzfeld, Michel and Rot, 2006 and Michel 2017.

${ }^{6}$ See, for example, images No.1 and No.14 in Bon \& Stéphani 2003. The images are referred to by their numbers here as the photographic plates are numbered separately from the pages featuring Bon's text. Sonnet's interest in the visual traces of industry is also reflected in her practice of documenting her own (re-)visits to sites such as Billancourt (http://www.martinesonnet.fr/Site/Billancourt.html) or the U4 blast furnace in Uckange (http://www.martinesonnet.fr/Site/Uckange U4.html ) in photographs shared on her website.

${ }^{7}$ Sonnet $(2012,210,213)$ uses the term 'texte-usine' to refer to her reconstitution of the world of the factory from archive material in alternate chapters of Atelier 62. Laurent Demanze $(2016,83)$ takes up the term in the title of his essay using it as lens through which to explore the text as a whole.

${ }^{8}$ Viart 2009 explores further the figure of the silent father in the récit de filiation. 